\title{
The "100 Lobsters" Project: A Cooperative Demonstration Project For Health Assessments Of Lobsters From Rhode Island
}

Jeffrey D. Shields

Virginia Institute of Marine Science

Kersten N. Wheeler

Virginia Institute of Marine Science

JA Moss

Virginia Institute of Marine Science

B Somers

K Castro

Follow this and additional works at: https://scholarworks.wm.edu/vimsarticles

Part of the Marine Biology Commons

\section{Recommended Citation}

Shields, Jeffrey D.; Wheeler, Kersten N.; Moss, JA; Somers, B; and Castro, K, "The "100 Lobsters" Project: A Cooperative Demonstration Project For Health Assessments Of Lobsters From Rhode Island" (2012).

VIMS Articles. 339.

https://scholarworks.wm.edu/vimsarticles/339

This Article is brought to you for free and open access by the Virginia Institute of Marine Science at W\&M ScholarWorks. It has been accepted for inclusion in VIMS Articles by an authorized administrator of W\&M ScholarWorks. For more information, please contact scholarworks@wm.edu. 


\title{
THE "100 LOBSTERS” PROJECT: A COOPERATIVE DEMONSTRATION PROJECT FOR HEALTH ASSESSMENTS OF LOBSTERS FROM RHODE ISLAND
}

\author{
JEFFREY D. SHIELDS, ${ }^{1 *}$ KERSTEN N. WHEELER, ${ }^{1}$ JESSICA MOSS, ${ }^{1}$ BARBARA SOMERS ${ }^{2}$ \\ AND KATHLEEN CASTRO ${ }^{2}$ \\ ${ }^{1}$ Department of Environmental and Aquatic Animal Health, Virginia Institute of Marine Science, The \\ College of William \& Mary, PO Box 1346, Gloucester Point, VA 23062; ${ }^{2}$ University of Rhode Island \\ Fisheries Center, East Farm Rd., Bldg. 83, Kingston, RI 02881
}

\begin{abstract}
The emergence of epizootic shell disease in the American lobster (Homarus americanus) has been devastating to the fishing industry in southern New England. In response, research was initiated to understand the roles of the environment, pathogens, and pollutants in the ecology and etiology of the disease. A comprehensive project was initiated in which tissues and hemolymph from 100 lobsters were collected from an endemic area of disease, Narragansett Bay, RI. The project has moved forward with the purpose of compiling, synthesizing, and propagating the findings from the "100 Lobsters" Project. The resulting tissue bank and Web-based data repository and instructional tools serve as a nascent demonstration project to both the scientific community working on this disease as well as to members of the lobster industry.
\end{abstract}

KEY WORDS: Homarus americanus, clawed lobster, epizootic shell disease, Long Island Sound, Narragansett Bay

\section{INTRODUCTION}

The American lobster (Homarus americanus, Milne Edwards) supports one of the largest crustacean fisheries in the world. American landings are valued at \$300-\$400 million annually (National Marine Fisheries Service Annual Landings Query, 2012), and Canadian landings are valued at $\$ 400-\$ 700$ million (Fisheries and Oceans Canada, 2012). Prior to 1999, the fishery for lobsters in Long Island Sound (LIS) was the third largest in the country, with landings valued at more than \$35 million for New York and Connecticut (National Marine Fisheries Service, NOAA, 2012). The lobster fishery remains a significant resource from LIS, accounting for more than $90 \%$ of the value of commercial fisheries landings in the region.

In 1996, lobsters from Narragansett Bay, RI, were observed with extensive necrosis of the cuticle. At the time it was thought to be classic, or endemic, shell disease. Classic shell disease was first described in the American lobster during the 1930s (Hess 1937). It gained attention during the early 1980s when it appeared during a survey of several locations along the coast of Massachusetts (Estrella 1984). The prevalence was moderate $(12 \%)$, and gross signs of minor pitting of the shell were not of concern to the New England lobster industry. By 1999 and 2000 , it was clear a more aggressive form of shell disease, now known as epizootic shell disease (ESD), was emerging in lobsters from the region (Castro \& Angell 2000). The epizootic form is characterized by deep, melanized lesions that can sometimes spread over the entire body of the lobster (Castro \& Angell 2000, Smolowitz et al. 2005a). From about 1997 to the present, ESD has appeared in lobsters from eastern LIS, Block Island Sound, Narragansett Bay (Castro \& Angell 2000, Castro et al. 2005, Landers 2005, Powell et al. 2005), and Buzzards Bay (Glenn \& Pugh 2005). It has spread into Cape Cod Bay and the Gulf of Maine, but at relatively low levels, and likely from migrations of affected lobsters into these regions (Glenn \& Pugh

*Corresponding author. E-mail: jeff@vims.edu DOI: $10.2983 / 035.031 .0203$
2005, Glenn \& Pugh 2006, Wilson 2005). The syndrome remains prevalent in eastern LIS and Block Island Sound, with prevalence ranging from $20-30 \%$ in adult lobsters (Cobb \& Castro 2006). Unfortunately, ESD has coincided with a decline in the quantity and quality of commercial landings of lobster (Cobb \& Castro 2006).

In response to the severe decline of the American lobster in the waters of LIS, concomitant with increased prevalence of emergent ESD, a \$2.3 million research initiative was funded to monitor and study lobster shell disease in the waters off the northeastern United States. Of the 25 proposals submitted to the New England Lobster Research Initiative, 9 were funded. Many of the research projects from that initiative are presented in this issue. They have led to an increased understanding of the syndrome (e.g., Chistoserdov et al. 2012, Homerding et al. 2012, Tarrant et al. 2012, Tlusty \& Metzler 2012), as well revealed new findings on lobster biology (Kunkel et al. 2012, Rycroft et al. 2012) and the presence of contaminants (Jacobs et al. 2012, Laufer et al. 2012, LeBlanc \& Prince 2012,) and other disease syndromes in lobsters (Magel et al. 2009, Shields et al. 2012). During the first year of the funding initiative, it became apparent that a more powerful analysis could be gained by coordinating the collection and analyses of tissue samples from a single, larger set of animals rather than from the typical approach in which animals are obtained separately for each investigator or laboratory.

The "100 Lobsters" Project arose from a discussion among lobster researchers at the $7^{\text {th }}$ International Lobster Conference in Charlottetown, Prince Edward Island, Canada, 2007. A paper by Comeau and Benhalima presented at that meeting reported on a strikingly similar condition to ESD in lobsters from Canadian waters (Comeau \& Benhalima 2009). Although the condition was extremely rare in lobsters in Canada, the histological assessment by Comeau and Benhalima (2009) indicated significant pathological alteration to the gonads in addition to widespread destruction of the cuticle. This observation led members of the New England Lobster Health Initiative to question whether other pathologies occurred in lobsters from eastern LIS and Narragansett Bay, RI, specifically 
in animals with heavy infections of ESD. In the current study, the gonads showed no obvious histological changes in association with ESD, but several idiopathic syndromes, including severe necrotizing hepatopancreatitis, were found in lobsters with and without the condition from within the endemic area of the disease (see Shields et al. 2012).

Our goal was to develop an understanding of ESD on one of New England's most economically important fisheries. The need to coordinate this activity resulted in the inception and development of the 100 Lobsters Project. A large number of lobsters from Narragansett Bay, RI, encompassing relatively similar numbers of male and female lobsters, with and without shell disease, were collected for further joint analyses. In addition, a group of lobsters from Maine were included to serve as controls for lobsters collected in Narragansett Bay, RI. The primary objective of the 100 Lobsters Project was to coordinate the collection of a common pool of tissues from lobsters with and without signs of ESD, and to provide these tissues to disparate laboratories to pool the information into an integrated assessment of the health status of each animal. The common pool of lobsters and analyses (metals, bacteriology, molecular expression studies, histology, and so forth) would facilitate correlative analyses on ESD. A single laboratory, the Disease Ecology Laboratory, VA Institute of Marine Science (VIMS), was designated to receive and process animals for tissues, preserving them according to the needs of the various research groups, then sending samples to collaborators (Table 1) for more specific processing and analyses. The secondary objectives were to create and maintain a database repository and interactive tool for ongoing studies on ESD. Such a tool could facilitate research on this significant disease issue as well as serve as a demonstration project on how to coordinate research on emerging disease issues in the marine environment.

\section{MATERIALS AND METHODS}

\section{Collection and Preprocessing of Lobsters}

Lobsters were collected from north of the Newport Bridge $\left(41^{\circ} .5073-71^{\circ} .3463\right.$ decimal degrees, $\left.35 \mathrm{~m}\right)$, Narragansett Bay in June, July, and October 2008. Animals were collected by commercial lobstermen using ventless, baited commercial lobster pots. Lobsters from Maine were collected from off Mount Dessert Rock, December 2008, by personnel from the Maine Department of Environmental Quality using commercial gear. Shortly after capture, lobsters were shipped in Styrofoam coolers packed with blue-ice bricks and moist newspapers to VIMS via overnight delivery. On arrival lobsters were sorted into 3 groups: those few that had died and were not fit for further processing (not included in the study), those that were moribund and required immediate dissection and processing, and those to be housed in a refrigerated aquarium (220 gal.) for short-term holding prior to processing (1-3 wk).

For initial processing, lobsters were examined for sex, carapace length (CL), shell condition, and injuries. Lobsters were rated as having no shell disease, or having shell disease intensities that were light, moderate, or heavy, depending on the relative proportion of affected to unaffected "shell" on the lobster, as in Landers (2005). Prior to processing and dissection, lobsters were photographed with a digital camera (Olympus Evolt-510).

\section{Tissue Sample Collection}

Prior to lobster dissection and processing, a complex datasheet was developed with investigators from the Lobster Health Research Initiative to facilitate the needs of the integrated analyses (Fig. 1). For dissection and processing, hemolymph was drawn with a $27-\mathrm{G}$. syringe from the juncture of the basis and ischium of the $5^{\text {th }}$ walking leg. The area was swabbed with $70 \%$ ethanol prior to bleeding. A few drops of hemolymph were dotted onto TCBS plates (Thiosulfate citrate bile salts sucrose agar, specific for Vibrio spp.) and incubated at room temperature for 24-48 h. Aliquots of hemolymph were stored in acetonitrile and RNAlater (Qiagen), as well as frozen neat at $-80^{\circ} \mathrm{C}$. Additional hemolymph was placed in an anticoagulant (Söderhäll \& Smith 1983), centrifuged at 2,600 rpm ( $630 \mathrm{~g}$, IEC) at $4^{\circ} \mathrm{C}$, and the plasma and hemocytes were stored separately at $-80^{\circ} \mathrm{C}$. Lobsters were then killed by injection with a 1-mL aliquot of ice-cold saturated $\mathrm{KCl}$ into the region of the ventral nerve ganglia, as in Battison et al. (2000). The ligaments around the carapace were severed with a knife, the carapace was

TABLE 1.

Research projects receiving samples from the 100 Lobsters Project as part of the New England Lobster Research Initiative.

\begin{tabular}{ll}
\hline \hline \multicolumn{1}{c}{ Primary Contact } & \multicolumn{1}{c}{ Project } \\
\hline Allam, B., Dove, A., McElroy, A. \& Taylor, G. & $\begin{array}{c}\text { Characterization of exoskeletal microbial communities and host } \\
\text { immune responses associated with epizootic shell disease in lobsters } \\
\text { The spread of lobsters shell disease: genetic and social barriers }\end{array}$ \\
$\begin{array}{l}\text { Atema, J., Smolowitz, R., Roberts, S., Gerlach, G. } \\
\text { Gillevet, P. \& Shields, J. D. }\end{array}$ & $\begin{array}{c}\text { Etiological and mortality studies into epizootic shell disease of the } \\
\text { American lobster }\end{array}$ \\
Kunkel, J. & $\begin{array}{l}\text { Mineralization of the lobster exoskeleton as a target of shell disease } \\
\text { A possible role of alkyl phenols in lobster epizootic shell disease }\end{array}$ \\
LeBlanc, L. & $\begin{array}{c}\text { Analysis of environmental contaminants in shell-disease versus } \\
\text { nonshell-disease lobsters }\end{array}$ \\
Smolowitz, R., Chistoserdov, A., Tlusty, M. \& Felder, D. & Microbiology of shell disease: environmental sources and diversity. \\
Tlusty, M., Smolowitz, R. \& Chistoserdov, A. & Environmental stress and susceptibility to shell disease: an assessment \\
& of structural deficiencies in shell formation at increased temperatures \\
Verslycke, T., Stegeman, J. \& McDowell, J. & A molecular approach to understanding shell disease
\end{tabular}

Primary contact refers to the lead person who received samples, not necessarily the principal investigator for the project. 


\begin{tabular}{lll}
\multicolumn{1}{c}{ LOBSTER SHELL DISE ASE PROJECT } & data sheet \\
ID\#_ & Date of collection & Collector \\
Collection location & Shell Disease? \\
CL & Disease Intensity \\
Injury & Molt stage (Pr, I, Ps) \\
Sex $(\mathrm{M}, \mathrm{F})$ & TCBS positive or negative \\
Date of Necrospsy &
\end{tabular}

\begin{tabular}{|c|c|c|c|c|c|c|}
\hline Sample ID & Sample ID & $\begin{array}{l}\text { Actual } \\
\text { Weight }\end{array}$ & Storage & Shell pieces & Sample ID & Storage \\
\hline Hemolymph & $4 \mathrm{ml}$ & & Acetonitrile & Carapace - disease & $\mathrm{X} 2$ & $95 \% \mathrm{EtOH}$ \\
\hline Hemolymph & $1 \mathrm{ml}$ & & RNA later & Carapace - healthy & $\mathrm{x} 2$ & $95 \%$ EtOH \\
\hline plasma & $1 \mathrm{ml}$ & & Spun/frozen & Carapace - disease & $\mathrm{X} 2$ & Frozen \\
\hline cells & & & Spun/frozen & Carapace - healthy & $\mathrm{X} 2$ & Frozen \\
\hline Hemolymph & $1 \mathrm{ml} \times 2$ & & Frozen & & & \\
\hline $\begin{array}{l}\text { Hepatopancreas } \\
\text { (HP) }\end{array}$ & $2-4 g$ & & Acetonitrile & Claw & $\mathrm{X} 2$ & Frozen \\
\hline Gill & $2-4 \mathrm{~g}$ & & Acetonitrile & Dorsal abdomen (D. abd.) & $\mathrm{X} 2$ & Frozen \\
\hline Muscle & $2-4 g$ & & Acetonitrile & Telson/Uropod (T/U) & $\mathrm{X} 2$ & Frozen \\
\hline Gonad & $2-4 g$ & & Acetonitrile & Ventral abdomen (V. abd.) & $\mathrm{X} 2$ & Frozen \\
\hline Epidermis & $1-2 \mathrm{~g}$ & & Acetonitrile & Ventral sternum (V. st.) & $\mathrm{X} 2$ & Frozen \\
\hline Epidermis & $\mathrm{X} 2$ & & Frozen & Leg piece (leg) & $\mathrm{X} 2$ & Frozen \\
\hline Hepatopancreas & Cassette 1 & & Bouin's & Soft Tissues for bank & $\mathrm{X} 2$ & Frozen \\
\hline Heart & Cassette 1 & & Bouin's & Carapace - disease & & $10 \% \mathrm{NBF}$ \\
\hline Gill & Cassette 2 & & Bouin's & Carapace - disease & & Acetonitrile \\
\hline Eyes & Cassette 3 & & \begin{tabular}{|l|}
1 in \\
Bouin's, 1 \\
frozen \\
\end{tabular} & Carapace - disease & Cassette 5 & Bouin's \\
\hline Epidermis & Cassette 1 & & Bouin's & Carapace - healthy & Cassette 4 & Bouin's \\
\hline Gonad & Cassette 1 & & Bouin's & & & \\
\hline Muscle & & & RNA later & Pleopod & & $95 \% \mathrm{EtOH}$ \\
\hline Gonad & & & RNA later & Tail or claws and gills & $\sim 20 \mathrm{~g}$ & $\begin{array}{l}\text { Whirlpack/frozen } \\
-20\end{array}$ \\
\hline Hepatopancreas & & & RNA later & Hepatopancreas & $\sim 20 \mathrm{~g}$ & $\begin{array}{l}\text { Amber jar/ frozen } \\
-20\end{array}$ \\
\hline
\end{tabular}

$\mathrm{X} 2$ refers to the number of samples take. Cassette 1,2, 3 refers to the label on the cassette for histology.

Figure 1. Sample data sheet for the lobster processing and dissection for the 100 Lobsters Project.

removed, and various tissues were dissected for later processing and analyses. Briefly, pieces of several tissues were removed, weighed, and placed in acetonitrile or RNAlater, or they were placed in separate $2-\mathrm{mL}$ tubes and frozen at $-80^{\circ} \mathrm{C}$ (Fig. 1). Samples of tissues were also placed in cassettes and fixed in Bouin's solution for later histological processing (see Shields et al. 2012). Pieces of the shell (carapace, abdomen, telson, uropods, pleopods, claws, and legs) of each lobster were stored in $95 \%$ ethanol, acetonitrile, or Bouin's solution, or they were frozen at $-80^{\circ} \mathrm{C}$ as part of a proposed tissue bank for later studies. Samples fixed in Bouin's solution were rinsed in tap water and transferred to $70 \%$ ethanol after $48 \mathrm{~h}$. Samples were shipped to collaborating laboratories on dry ice in Styrofoam shipping boxes using express overnight delivery services.

\section{Database Development and Repository}

Excel and Access software (Microsoft) packages were used to input data and to manage the database structure. Dream- weaver software (Macromedia, Inc.) was used to develop and refine the Web interface with the Access database for data entry and report generation. Dreamweaver was also used for Webbased design, Java scripting, and linking tools for external users. The entire system was run on a Cold Fusion server with remote access granted freely to users; however, the data in the database reside on a secure server and can only be modified through approved users at VIMS. Researchers from other laboratories mailed Excel files to users at VIMS for uploading and final quality assurance and quality control.

\section{RESULTS}

\section{Overview of the Database}

Lobsters from Narragansett Bay, RI, were selected for the study based on their sex and infection status with ESD. There were 90 animals from RI, comprised of 57 female and 33 male lobsters. Of these, 43 did not have shell disease ( 23 females and 
20 males), and 47 had ESD ( 34 females and 13 males). For those animals with ESD, 12 were categorized with light infections (1$10 \%$ of their carapace covered), 14 with moderate infections (11-50\% of their carapace covered), and 21 with heavy infections ( $>50 \%$ of their carapace covered) as in Landers (2005) (Fig. 2). Lobsters from Mount Desert Rock, ME, were selected to match the relative sizes and sex ratio of the animals processed from Rhode Island. There were 19 lobsters from Maine, comprising 9 females and 10 males; none had signs of shell disease.

Currently, the database for the 100 Lobsters Project contains data from several, but not all, of the research groups. Data are available on meristic and morphological data, metals, and histological assessments of the cuticle (Fig. 3). Methods for the collection of data are given in respective papers on metal contaminants in the tissues and sediments (LeBlanc \& Prince 2012), and histological assessments of the cuticle (Smolowitz, unpubl. data). Other data sets have been submitted for inclusion in the database, but have not been added at this time. These include data on the bacterial communities (Meres et al. 2012), the histological assessment of the tissues (Shields et al. 2012), and molecular expression data from some of the affected animals (Tarrant et al. 2012).

The growing database is available online at http://www.vims. edu/research/departments/eaah/lobsterdisease/ (Figs. 3 and 4), with reprints and other information available at http://www.vims. edu/research/departments/eaah/programs/crustacean/research/ lobster_shell_disease/index.php.

Capturing the disparate data into a usable database was done by merging Excel files sorted by the common character of identification number. In some cases, Excel files from research groups were modified slightly to allow for better incorporation into the database. For example, metals data were resorted by metal, and the labels for the data were altered to make them easier to incorporate into the Access database. For histological analysis of the cuticle, the data were often read from more than one histological slide. Therefore, some editing was done to make the data sets more compatible, yet to retain their integrity. In cases where editing was done, the modifications were discussed with the researchers to ensure accuracy and appropriate representation.

\section{DISCUSSION}

The 100 Lobsters Project was developed as a means of coordinating research on ESD through the sharing of tissues and samples among researchers from disparate institutions. This type of integrated data sharing has the potential to develop into a powerful correlative tool for examining the etiology and ecology of ESD (Fig. 4). The concept for the project occurred midstream in the funding cycle; thus, no additional funding was available for collective sampling of the "100 lobsters" during the initiative's funding timeframe. Nonetheless, several research groups analyzed tissue samples from these animals and provided data sets to the project to establish the database. However, the 100 Lobsters Project remains incomplete. Future developments include improving the user interface, adding new data sets, expanding the correlative analyses, and incorporating more of the existing literature on shell disease into the database.

ESD has a complex etiology; however, several research projects have explored the potential proximate and ultimate causes of the syndrome. A leading possibility is that a compromised cuticle - through physical damage (Quinn et al. 2012) or contaminants such as alkyl phenols that could interfere in the synthesis, deposition, or maintenance of the cuticle (Jacobs et al. 2012, Laufer et al. 2012) - has an increased susceptibility to bacterial degradation. The changes to the cuticle result in a significant shift in the bacterial community, a dysbiosis, with certain members of that community, such as Aquimarina 'homari' and others, utilizing the weakened matrix of the cuticle

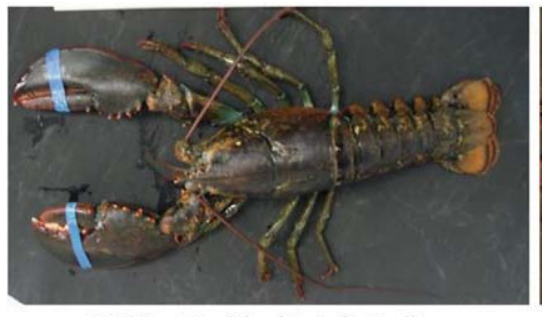

RI001 - Healthy (Uninfected)

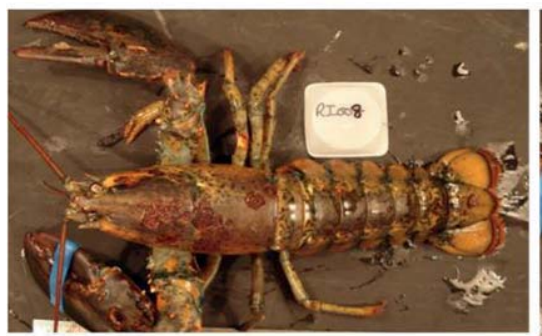

RI008 - Moderate Infection

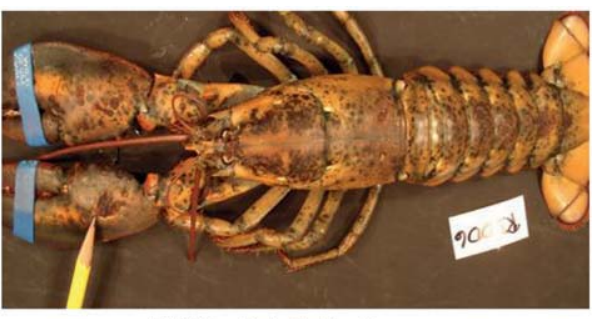

RI006 - Light Infection

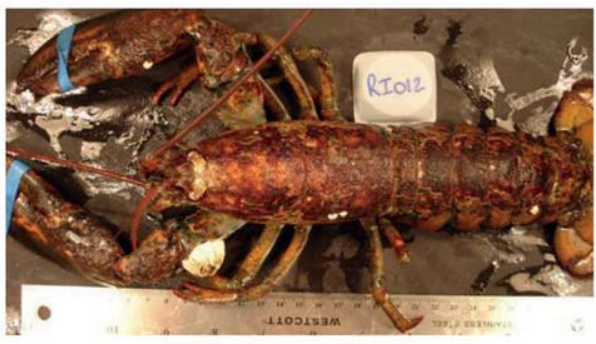

RI012 - Heavy Infection

Figure 2. Lobsters from the 100 Lobsters Project with varying states of epizootic shell disease. RI001 is a healthy lobster without signs of disease. RI006 has a light infection with $1-10 \%$ of the carapace or shell covered with lesions characteristic of the disease. RI008 has a moderate infection (11-50\% of the carapace covered by the lesions). RI012 has a heavy infection with more than $\mathbf{5 0} \%$ of the carapace affected by the syndrome (severity as in Landers (2005)). 


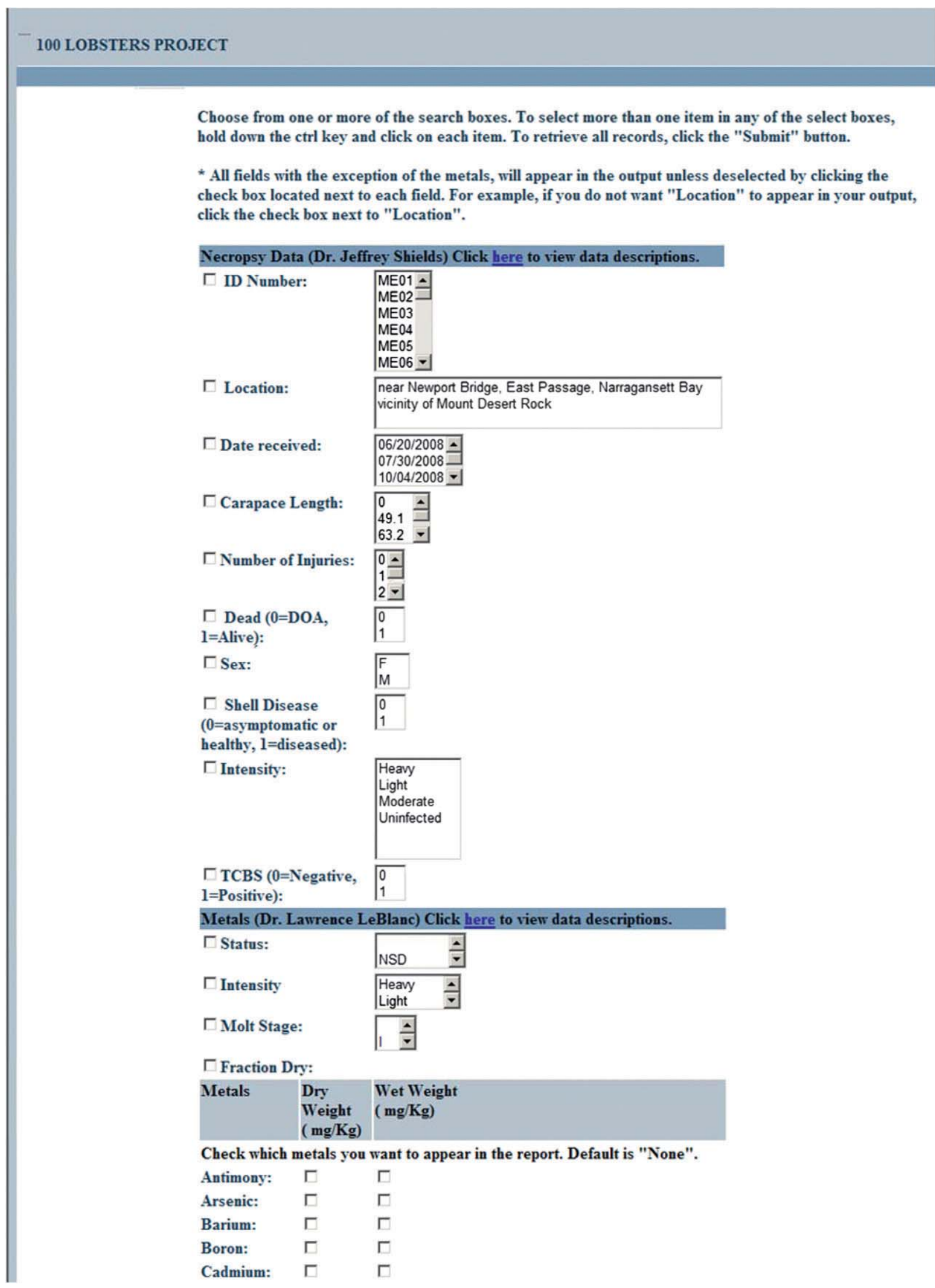

Figure 3. Portion of the database interface for the 100 Lobsters Project showing selection boxes for searches for basic data as well as some of the metals data and menus for selecting specific search requirements. A submit button (not shown) is at the bottom of the selection area. The database can be found at http://www.vims.edu/research/departments/eaah/lobsterdisease/. 


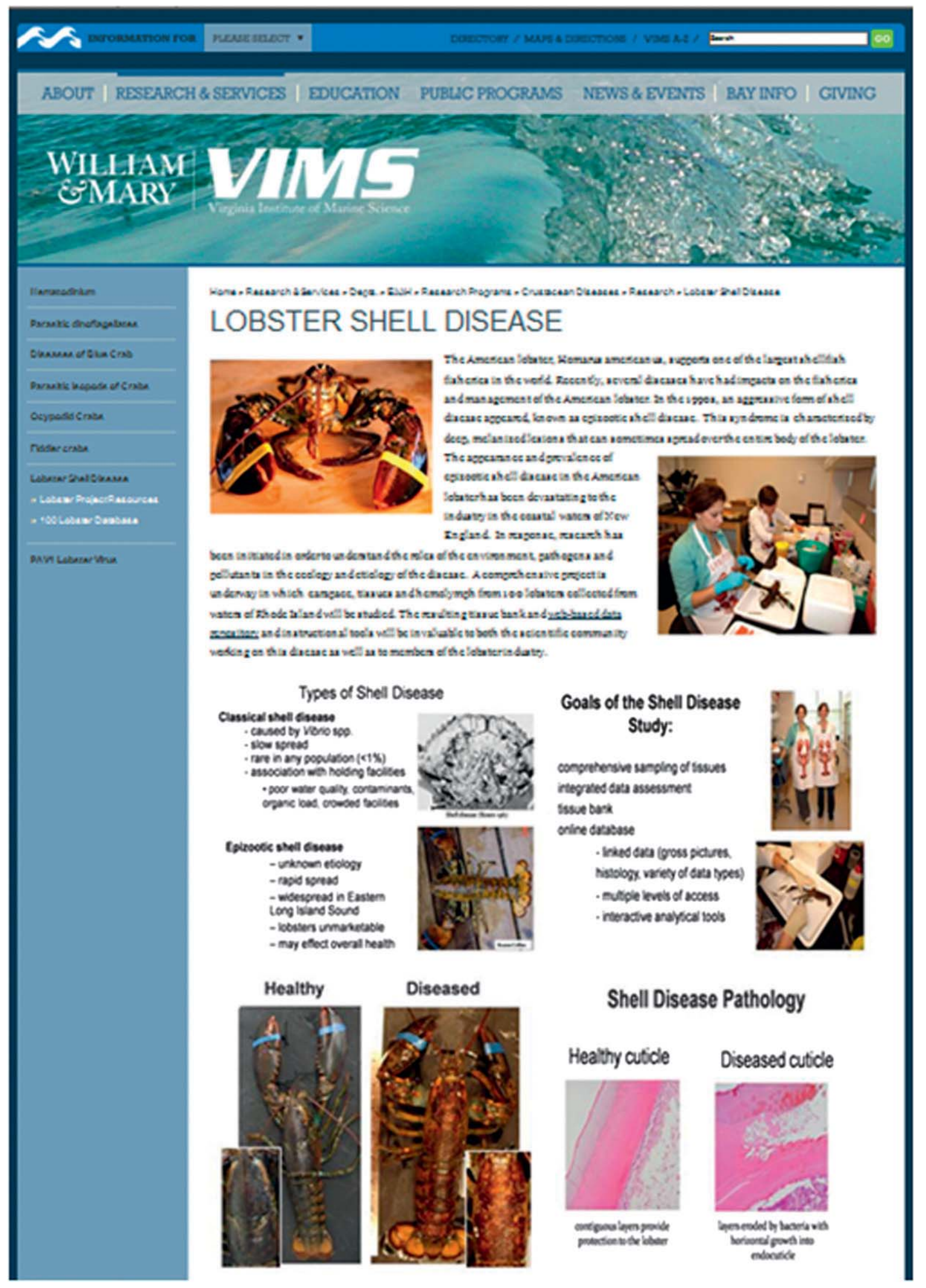

Figure 4. Frontispiece for the 100 Lobsters Project showing basic information on shell disease and the portal to the 100 lobsters database as well as a portal for additional publications on the syndrome. The URL for the site is http://www.vims.edu/research/departments/eaah/programs/crustacean/ research/lobster_shell_disease/index.php. 
for growth (Chistoserdov et al. 2012, Meres et al. 2012, Quinn et al. 2012). The bacterial community weakens the cuticle through enzymatic degradation, primarily from chitinolases, lipases, and proteases (Bell et al. 2012). The host defensive response to the syndrome indicates an altered immune response (Homerding et al. 2012) as well as altered expression of key synthetic pathways (Tarrant et al. 2012). There is also evidence of genetic selection occurring in lobsters off Rhode Island, with population differences occurring over finer scales than once thought possible (Atema, pers. comm.). Thus, the complexity of the syndrome lies in the interplay between the environment (climatic variability, increasing $\mathrm{pH}$ and temperatures), contaminants (polycyclic aromatic hydrocarbons, metals, organic contaminants above sediment guidelines), and the biology and physiology of the lobsters living within an altered landscape.

\section{LESSONS FROM THE 100 LOBSTERS PROJECT}

There are several lessons to be learned from designing and implementing a collaborative project such as the 100 Lobsters Project. First, the databank may require significant physical resources in terms of freezer space, storage and curation of samples. The long-term storage of tissues should be evaluated carefully because some analyses cannot provide meaningful data on frozen tissues held for long periods of time. Second, a determination must be made whether whole animal carcasses should be retained frozen. We chose not to retain carcasses because of limitations on freezer space, and that will limit the amount of resampling of cuticle that can be done in the future. Third, there is a plethora of data and metadata to be obtained and managed. As an example, one of the problems that we faced was how to catalog and make accessible the myriad photographs of each animal. Each animal has at least 3-5 photographs associated with it. We wanted to make these available in the database, but linking 300-500 individual photographs was not the best use of our limited resources. We have yet to resolve this to our satisfaction. Similarly, the histological assessments included numerous photographs that we plan to link and make accessible through the database. Fourth, data are not always obtained in a rectangular statistical format. We have not incorporated such data into the database; much of it will likely be included as embedded images rather than as linked data sets. Some analyses and data will simply be included as published references from work arising from the New England Lobster Health Initiative. Fifth, coordinating the collection of processed data requires significant oversight. Researchers often multitask on multiple projects; hence, obtaining data in a timely fashion can and was a significant impediment to the development of the project. We are still missing or have only fragments of several data sets, and have few resources left to integrate tardy submissions into the existing framework. Last, and most important, this project would have benefited greatly if it had been included in the planning for the funding initiative rather than included late during the process. We believe such demonstration projects have great potential to improve our understanding of complex or difficult problems that are often tackled by interdisciplinary teams. Coordinated sampling and integrative analyses have a lot to offer in the study of emerging diseases in the marine environment, and the management of data collecting and archiving requires an infrastructure, and oversight should be included during initial phases to address such emergent phenomena.

\section{ACKNOWLEDGMENTS}

We thank Tom Angell and Dan Costa from the Rhode Island Department of Environmental Management, and lobsterman Steve Seymour for his able collection of lobsters from Rhode Island. We are grateful to Melissa Smith and Kathleen Reardon, Maine Department of Marine Resources, for obtaining lobsters from Maine. Bobbi Rawlings at VIMS helped with the database design and implementation. This work was supported by the National Marine Fisheries Service as the New England Lobster Research Initiative: Lobster Shell Disease under NOAA grant NA06NMF4720100 to the University of Rhode Island Fisheries Center. The views expressed herein are those of the authors and do not necessarily reflect the views of NOAA or any of its subagencies. The U.S. government is authorized to produce and distribute reprints for government purposes, notwithstanding any copyright notation that may appear hereon. This is contribution no. 3212 from VIMS.

\section{LITERATURE CITED}

Battison, A., R. MacMillan, A. MacKenzie, P. Rose, R. Cawthorn \& B. Horney. 2000. Use of injectable potassium chloride for euthanasia of American lobsters (Homarus americanus). Comp. Med. 50:545-550.

Bell, S. L., B. Allam, A. McElroy, A. Dove \& G. T. Taylor. 2012. Investigation of epizootic shell disease in American lobsters (Homarus americanus) from Long Island Sound: I. Characterization of associated microbial communities. J. Shellfish Res. 31:473-484.

Castro, K. M. \& T. E. Angell. 2000. Prevalence and progression of shell disease in American lobster, Homarus americanus, from Rhode Island waters and the offshore canyons. J. Shellfish Res. 19:691-700.

Castro, K., T. Angell \& B. Somers. 2005. Lobster shell disease in southern New England: monitoring and research. In: M. F. Tlusty, H. O. Halvorson, R. Smolowitz \& U. Sharma, editors. Lobster shell disease workshop. Aquatic Forum Series 05-1. Boston, MA: New England Aquarium. pp. 165-172.

Chistoserdov, A. Y., R. A. Quinn, S. L. Gubbala \& R. Smolowitz. 2012. Bacterial communities associated with lesions of shell disease in the American lobster, Homarus americanus Milne-Edwards. J. Shellfish Res. 31:449-462.
Cobb, J. S. \& K. M. Castro. 2006. Shell disease in lobsters: a synthesis. Report prepared for the New England Lobster Research Initiative. Rhode Island Sea Grant. Kingston, RI. http://seagrant.gso.uri.edu/ lobster_initiative/documents/SD_SynthesisFinal.pdf. 18 pp.

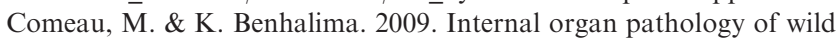
American lobster (Homarus americanus) from eastern Canada affected with shell disease. N. Z. J. Mar. Freshw. Res. 43:257-269

Estrella, B. T. 1984. Black gill and shell disease in the American lobster (Homarus americanus) as indicators of pollution in Massachusetts Bay and Buzzards Bay. Massachusetts Division of Marine Fisheries publication no. 14049-19-125-5-85-CR. Boston, MA. 17 pp.

Fisheries and Oceans Canada. 2012. http://www.dfo-mpo.gc.ca/stats/ commercial/sea-maritimes-eng.htm. Accessed April 27, 2012.

Glenn, R. \& T. L. Pugh. 2005. Observations on the chronology and distribution of lobster shell disease in Massachusetts coastal waters. In: Tlusty, M. F., H. O. Halvorson, R. Smolowitz \& U. Sharma, editors. Lobster shell disease workshop. Aquatic Forum Series 05-1. Boston, MA: New England Aquarium. pp. $141-155$. 
Glenn, R. \& T. L. Pugh. 2006. Epizootic shell disease in American lobsters (Homarus americanus) in Massachusetts coastal waters: interactions of temperature, maturity, and intermolt duration. J. Crustac. Biol. 26:639-645.

Hess, E. 1937. A shell disease in lobsters (Homarus americanus) caused by chitinivorous bacteria. J. Biol. Board Canada 3:358-362.

Homerding, M., A. McElroy, G. Taylor, A. Dove \& B. Allam. 2012. Investigation of epizootic shell disease in American lobsters (Homarus americanus) from Long Island Sound: II. Immune parameters in lobsters and relationships to the disease. J. Shellfish Res. 31:495-504.

Jacobs, M., H. Laufer, J. Stuart, M. Chen \& X. Pan. 2012. Endocrinedisrupting alkyl phenols are widespread in the blood of lobsters from southern New England and adjacent offshore areas. J. Shellfish Res. 31:563-571.

Kunkel, J. G., W. Nagel \& M. J. Jercinovic. 2012. Mineral fine structure of the American lobster cuticle. J. Shellfish Res. 31:515-526.

Landers, D. F. 2005. Prevalence and severity of shell disease in American lobster Homarus americanus from eastern Long Island Sound, Connecticut. In: M. F. Tlusty, H. O. Halvorson, R. Smolowitz \& U. Sharma, editors. Lobster shell disease workshop. Aquatic Forum Series 05-1. Boston, MA: New England Aquarium. pp. 94-97.

Laufer, H., M. Chen, M. Johnson, N. Demir \& J. M. Bobbitt. 2012. The effect of alkyl phenols on lobster shell hardening. J. Shellfish Res. 31:555-562.

LeBlanc, L. A. \& D. Prince. 2012. Metal concentrations in tissues of American lobsters (Homarus americanus, Milne-Edwards) with epizootic shell disease. J. Shellfish Res. 31:543-553.

Magel, D. R., J. D. Shields \& R. Brill. 2009. Idiopathic lesions and visual deficits in the American lobster (Homarus americanus) from Long Island Sound, NY. Biol. Bull. 217:95-101.

Meres, N. J., C. C. Ajuzie, M. Sikaroodi, M. Vemulapalli, J. D. Shields \& P. M. Gillevet. 2012. Dysbiosis in epizootic shell disease of the American lobster (Homarus americanus). J. Shellfish Res. 31:463-472.

National Marine Fisheries Service, NOAA. 2012. http://www st.nmfs.noaa.gov/st1/commercial/landings/annual_landings.html. Accessed April 27, 2012.
National Marine Fisheries Service. 2003. Fisheries of the United States, 2002. Office of Science and Technology, Fisheries Statistics and Economics Division. Silver Spring, MD: US Dept. Commerce. 127 pp.

Powell, P., C. Giannini \& J. Benway. 2005. Status of shell disease in Long Island Sound. In: M. F. Tlusty, H. O. Halvorson, R. Smolowitz \& U. Sharma, editors. Lobster shell disease workshop. Aquatic Forum Series 05-1. Boston, MA: New England Aquarium. pp. 106-114.

Quinn, R. A., A. Metzler, R. M. Smolowitz, M. Tlusty \& A. Y. Chistoserdov. 2012. Exposures of Homarus americanus shell to three bacteria isolated from naturally occurring epizootic shell disease lesions. J. Shellfish Res. 31:485-493.

Rycroft, N., K. Radcliffe, E. McDougal, J. Halverson, G. Gerlach, J. Deppermann \& J. Atema. 2012. No olfactory recognition of shell disease in the American lobster, Homarus americanus. J. Shellfish Res. 31:527-532.

Shields, J. D., K. N. Wheeler \& J. A. Moss. 2012. Histological assessment of the lobsters (Homarus americanus) in the "100 Lobsters" Project. J. Shellfish Res. 31:431-438.

Smolowitz, R., A. Y. Chistoserdov \& A. Hsu. 2005a. A description of the pathology of epizootic shell disease in the American lobster, Homarus americanus H. Milne Edwards 1837. J. Shellfish Res. 24: 749-756.

Söderhäll, K. \& V. J. Smith. 1983. Separation of the haemocyte populations of Carcinus maenas and other marine decapods, and prophenoloxidase distribution. Dev. Comp. Immunol. 1:229-239.

Tarrant, A. M., D. G. Franks \& T. Verslycke. 2012. Gene expression in American lobster (Homarus americanus) with epizootic shell disease. J. Shellfish Res. 31:505-513.

Tlusty, M. F. \& A. Metzler. 2012. Relationship between temperature and shell disease in laboratory populations of juvenile American lobsters (Homarus americanus). J. Shellfish Res. 31:533-541.

Wilson, C. 2005. Observations of shell disease in coastal Maine waters: 2003 and 2004. In: M. F. Tlusty, H. O. Halvorson, R. Smolowitz \& U. Sharma, editors. Lobster shell disease workshop. Aquatic Forum Series 05-1. Boston, MA: New England Aquarium. pp. 156-161. 